\title{
Portrayals of corporate social responsibility: A comparative analysis of a Russian and a Canadian newspaper*
}

\author{
Julia Rozanova ${ }^{* *}$
}

The general public learns about the social role of corporations from the media, yet little research has been conducted into the media portrayals of corporate social responsibility, particularly in the post-communist countries. Analysis revealed that in both countries corporate social responsibility was portrayed from the perspectives of the enterprises, the state, and the civil society. While there were similarities in the depictions of types of social activity undertaken by corporations in the two countries, significant differences emerged as well. The influence of the state was emphasized in the Russian articles, while the Canadian articles focused on the role of the civil society. The paper places the findings in the theoretical context of the social role of business in different institutional settings, and points out directions for further research into the media representation of corporate social responsibility.

Die Öffentlichkeit hört über die soziale Rolle der Aktiengesellschaften aus den Medien, es wurden jedoch nur wenige Forschungen im Bereich der Darstellung durch die Medien durchgeführt, insbesondere in ehemalig kommunistischen Ländern. Analysen enthüllten dass in Russland und Kanada die soziale Verantwortung Aufgabe der Unternehmen, des Staates und der Zivilgesellschaft war. Es gab Gemeinsamkeiten, aber auch Unterschiede in den Typen der sozialen Betätigung. Der Einfluß des Staates wurde in den russischen Artikeln betont, wohingegen die kanadischen Artikel die Rolle der Zivilgesellschaft hervorhoben. Der Aufsatz platziert die Ergebnisse im theoretischen Kontext der sozialen Rollen von Unternehmen und weist auf weitere Forschungen in der Medienrepräsentation von sozialer Verantwortung von Aktiengesellschaften hin.

Key words: Corporate social responsibility / media portrayals / Russia / Canada

\footnotetext{
Manuscript received: 20.05.05, accepted: 23.01 .06 (1 revision)

** Julia Rozanova, University of Alberta, Department of Sociology. Main research areas: Social role of business, media, ageing in organizations, gender in organizations, industrial relations, human resources management Corresponding address: rozanova@ualberta.ca
} 


\section{Introduction}

By virtue of pursuing their goals, corporations are pictured in literature as sources of both destruction and support in the development and implementation of the social policy regimes. On the one hand, they lobby governments worldwide to deregulate, reduce taxes, and curtail welfare spending. On the other hand, they are seen as starting to accept and perform social functions that go beyond the immediate needs of capitalist production. Corporate social responsibility, its extent and implications remain a heavily contested terrain. While many see it as a very positive phenomenon, some (Mendes 2003; Rozanova 2005) warn against hopes that socially responsible corporations may replace governments as social policy providers. By adhering to the principles of social partnership and through charitable donations, corporations invest into their social and political capital anticipating it to translate into higher economic returns in the future. While business operations may positively contribute to social policy, corporate mandate is not to resolve all the social problems. Thus expecting corporations to fill the social spaces vacated by the state is unrealistic because in building a positive public image, corporations ultimately pursue their business goals.

Despite abundant research on corporate social responsibility, little is known about the role that the media play in its design and implementation. In particular, the socially responsible images that the media help corporations to build have received little attention, especially in the Eastern European countries. Yet, this question merits careful analysis, both theoretically and practically. Since the media in most developed countries are increasingly controlled by a few powerful corporations it calls for a critical examination of the media portrayals of corporate social responsibility and discerning the agendas and interests underlying them. My essay starts filling the gap through knowledge and exploration of corporate social responsibility discussions in the newspaper articles published in The Globe and Mail and in Nezavisimaya Gazeta in 2004. Given the relevance of the question whether corporations play different social roles in different societies, and whether these differences are reflected in their media portrayals, a cross-national comparison is particularly interesting (Patton 2002). Despite the obvious differences in terms of economic and political history, the two countries share important similarities in terms of climate, geography and the resource industries being the foundation of economic wealth. The paper will discuss whether despite historical, political, economic and cultural differences there are any similarities in the assertions and attitudes expressed in the newspaper portrayals of corporate social responsibility in the Canadian and the Russian newspaper. 


\section{Corporate social responsibility in Russia and in the West: concept and history}

The existing literature discusses corporate social responsibility from different perspectives, all of which would be a task beyond the scope of the current essay. Thus, I will only outline several key points in terms of the role that corporations play in social development.

The concept of corporate social responsibility considers the private sector, including trans-national companies, as the potential agents of social development. A more responsible approach of corporations to labour relations, environmental management, and community development should lead to improved reputation and hence higher profits (Marsden 2000). The key paradox of corporate social responsibility (Marsden 2000; Rozanova 2005) is that corporations are simultaneously held responsible for much of the social and environmental degradation, yet considered as crucial allies in fighting these negative impacts.

The first part of this paradox draws on the arguments of international political economists and welfare state researchers (Scharpf/Schmidt 2000; Strange 2000; Leibfried 2001). They stated that unlike natural persons, corporations are immune from the social control and have no conscience (Galaskiewicz 1991). Mobile firms may pick and choose among production locations, driving towards the bottom and looking for the most attractive, that is, the least regulated investment opportunities worldwide. Such behavior is labeled 'social dumping'. Thus international firms may create "an institutional base of their own to motivate and retain employees and sustain support for R\&D and technical development; but isolated firms like that are likely to imply considerable social inequality" (Crouch/Streeck 1998:16).

The second part of the paradox is that corporations may be obliged to fill the social spaces vacated by the governments that curtail social spending. Corporations may engage involuntarily, to prevent the social decay from interfering with the safety of their business operations (Peregudov, 2000; Rozanova, 2005). However, Strange (2000) pointed out that corporations are quite resilient to social degradation in their operating environment. Also, the most powerful corporations such as the multinationals have the ability to relocate, and thus are practically immune from either too much (and consequently heavy regulation and taxation) or too little (and consequently considerable social inequality) welfare state presence. Thus while large corporations sometimes may find it cost-efficient to socialize their industrial and social risks (McDaniel 1997; Mares 2001), the question remains under what conditions will the firm decide to support the overall social development rather than to attend to the risks at the enterprise level. 
A few words need to be said now about the conceptualization of corporate social responsibility in the West and in Russia. Corporate social responsibility as the synergy between the business and the civil society institutions was theoretically conceptualized in the West during the 1960s and 1970s, when most big companies started establishing connections with the communities and NGOs (particularly the ecological organizations and associations of consumers), often through the public relations departments (Rozanova 2005). With regards to intra-corporate relations with the employees, the most common forms of corporate 'social welfare' included corporate insurance for pensions and medical services, and professional (re)training. Socially responsible behaviour towards the employees also signified promotion of collaboration between the management and the employees and inclusion of the latter into decision-making (Rozanova 2005:206).

The relevance of the corporate social responsibility concept started decreasing in the West at the time of the 'new conservatives' with R. Reagan and M. Thatcher. In a climate that favoured minimizing social costs, corporations felt less obligated to commit to any responsibility towards the society. However, the pressure (often at the international level) from the civil society and NGOs against the anti-social practices of big business necessitated some response, and corporations started promoting their socially friendly image through the mass media.

The social patronage of the Soviet socialist type was different from the corporate social responsibility of the Western type. The former signified provision of an extensive range of essential social services (housing, medical services, child care, recreational facilities, etc.) to employees and their families, while the latter meant the social dimension of businesses' interactions with employees, communities, and the civil society (Zhiltsov 1995). After the disintegration of the Soviet Union in 1991, the Russian government adopted the course of the economic policy reforms in line with the Washington consensus, when the social needs (including such fundamental ones as healthcare) came second to quick economic development at any cost (Rimashevskaya 2005). The comprehensive social infrastructure system ('Sotzialka') became unaffordable to enterprises, and was discarded first as a spontaneous reaction to the collapse and crisis, and then in a deliberate effort to reduce the production costs during restructuring and privatization.

During the 1990s, most of the Russian companies radically disentangled themselves from the traditions of Soviet patronage. Adopting the extreme neoliberal principles of 'profits come first', all but a few Russian companies ignored that their Western counterparts, especially when operating at home and in their relationships with the local communities, are pressured by public opinion and the NGOs to adhere to the goals of social development. Yet a few Russian businesses, most notably the richest companies in the extraction industry, 
sustained comprehensive social benefits systems for their employees, and maintained the social infrastructure within the communities and regions of their operation ${ }^{1}$.

As Peregudov (2000) pointed out, it would be a mistake to believe that either in Russia or in the West, corporations fully accept the principles of socially responsible behaviour as their modus operandi. In the Russian case, the corporations considered the social development activities as temporary solutions until the government gets back on its feet after the crisis, while in the West corporations' main concern was their public image rather than sustainable solutions to social problems (Mendes 2003). Thus the central theoretical and practical question in the discussion of corporate social responsibility is whether it remains a voluntary choice of the business or should be ensured through formal control (Marsden 2000; Mendes 2003). While there is no consensus regarding the answer to this question, in Russia, unlike in the West, the state has traditionally made a significant influence on the participation of business in social policy (Rozanova, 2005). This tendency draws on the central planning model of the state-business interaction originating from the Soviet times, and was reinforced during Putin's presidency when the state officials started encouraging the business to take on significant social commitments (Krasin 2004). Moreover, researchers of the institutional diversity of capitalism pointed out different models of state-business interaction in different Western countries (Hall/Soskice 2001). The Anglo-Saxon countries have a liberal Laisser-Faire model, characterised by reliance on the market mechanisms with minimal interference from the state, while the continental European countries preserve a coordinated market economy model with a strong public sector, and the Scandinavian countries adhere to the public policy supremacy model, when the welfare state moderates the functioning of the market in line with the goals of social inclusion and social development (Hall/Soskice, 2001). The economic behavior of actors (states and corporations) is thereby institutionally embedded (Powell/DiMaggio 1991; Salais 1998). The institutions are the outcomes of a compromise between alternative models of justice, alternative visions on the attainment of a public good, mobilized in the actions of economic agents (businesses, states and individuals), in collective action and perpetuated in social attitudes. The institutional framework is especially relevant to discriminate between the social activities businesses carry out due to legal obligation, and those they do voluntarily. The rules and laws cannot be considered simply as causes of action, but rather as results of pragmatic interactions and a

${ }^{1}$ For detailed analysis of the specific examples from the history of privatization in the extraction industry and subsequent restructuring and social activities of the privatized companies, see Lane (1999) and Rozanova (2005), pp. 209-210. 
compromise between the capacities of the actors and the adaptation of their intentions to the environment (Salais 1998).

A few words must be said now about the issue of the media representation (of corporate social responsibility), and the controversial history of media ownership in Russia.

\section{Media system in Russia and theories of media representation}

The transformation of the media system from USSR to Russia had three phases (Chumikov 2002; Rozanova 2006 in press): the totalitarian phase (until 1985 and perestroika), the phase of unlimited freedom (the beginning of the 1990s), and the period of dirigible democracy (starting from 2000). In the USSR the media system was under rigid ideological, administrative, financial and political control of the state. Although the media of mass communication had high priority in the state budget, state support was a means of manipulation. The phase of unlimited freedom that began after the collapse of the USSR was marked by the creation of the new media market, when the senior state officials openly or tacitly supported the interests of the emerging media business sector. During that time privatization of the media took place. The oligarchs were buying regional electronic media in bulk, and establishing new print media, for political, rather than commercial, reasons. Initially owners did not expect their property to yield economic profits, appreciating the media only as a means of political influence. As democratic reforms continued and economic and political situation stabilized after the 1998 default, proprietors of the media became increasingly interested in their economic efficiency. However, during the period of dirigible democracy (after the coming of President Putin to power), the state re-introduced administrative and political pressure on the media (including the right to appoint chief executives of publishing houses and television channels), but did not supplement it with increased funding from the state budget. Thus both the print and the electronic media found themselves in a situation of double dependency - from the state bureaucracy and from the advertisers, which continued to be the major source of their revenue.

Research into the transformation of the Western media landscapes indicated that both electronic and print media are increasingly concentrated in the hands of a few multi-national media holdings, which employ universal branding strategies across countries and across different kinds of media (Calabrieze/Burgelmann 1999; Caldwell 2004). As Spigel (2001:14) argued, whatever the structure of a media system, the media content always reflects a reason with which it has been produced: "nothing is written without some intent, some power relations between those who record their history and those who don't." Thus the theories of media representation are highly relevant to the current analysis, but cannot be 
discussed at length here. Therefore I will only briefly introduce the crucial arguments within media research particularly salient for my study ${ }^{2}$.

The issues of media representation are central in the work of Hartley (1982), van Dijk (1988), Fowler (1991), and Fairclough (1995) who address them from the semiotic and socio-linguistic perspective. Unlike critical theorists (Horkheimer 1975; Habermas 2000), who blame the media bias on the imperfections of the capitalist economic relations underlying media production, social linguists argue that no media system may be neutral by definition, because any media system inevitably mediates or 'represents' the news by making it through processes of skewing and judgement (Fowler 1991:12-13). Rather than saying that the media serve the ruling classes de jour, social linguists argue that anything that is said or written about the world is articulated from a particular ideological position. "News is not simply that which happens, but that which can be regarded and presented as newsworthy. The criteria for newsworthiness may be unconscious in editorial practice, but are socially constructed and perform a gate keeping role, filtering and restricting news input" (Fowler 1991:13). Thus any news is always reported from the perspective of some beneficiary "because the institutions of news reporting and presentation are socially, economically, and politically situated" (Fowler 1991:10). This results in "partiality, not only in what assertions and attitudes are reported - a matter of content - but also in how they are reported - a matter of form or style, and therefore... of ideological perspective" (Fowler 1991:22-23). Although the 'what' and the 'how' are of course interconnected, this essay focuses predominantly on what assertions and attitudes are reported by the articles on corporate social responsibility published in the two newspapers, leaving the questions of how for further research.

\section{Methodology}

Data analysed in this paper are hard copy articles on corporate social responsibility published in Nezavisimaya Gazeta and in The Globe and Mail in 2004. The methodological approach is thematic analysis, placing the content of the newspaper texts in the socio-political and economic context. News stories are first analysed to discern the terrain and the trends of corporate social responsibility, and then combed for key themes, sorted and re-combed for tensions, contradictions, and realities of corporate social responsibility practices and problems. In analyzing news stories, which are treated as qualitative data, quotes are utilized to exemplify the themes, the common approach of

2 For a more detailed discussion of the media theories of representation, see Wetherell/Taylor/Yates (2001). 
sociological qualitative analysis of media content (McDaniel 1997; Denzin/Lincoln 2000; Silverman 2000; Patton 2002) ${ }^{3}$.

The period over which the articles were collected is January to December 2004. A year is conventionally considered by media researchers as a period of study sufficiently long enough to be representative of the scope of articles in an edition, and ruling out potential seasonal variations (Ryan/Bernard 1999). Nezavisimaya Gazeta and The Globe and Mail were chosen as quality print news media with comprehensive business sections that are referred to and portray themselves as national newspapers in their countries. Like most research methodologies, the conclusions are only valid within the selected universe, but they provide the opportunity to develop more general hypotheses and insights that may be tested in further studies.

The articles were included into the data set by means of purposeful sampling, using the intensity strategy. As Patton (2002:230) states, intense purposeful sampling focuses on selecting information-rich cases whose study will illuminate the issues that are being researched. The search of the electronic databases of both newspapers was conducted using the key words 'corporate social responsibility', 'socially responsible company /business /enterprise /behaviour', 'socially responsible entrepreneur', and 'social goals of businesses'. The searches were conducted in English for The Globe and Mail and in Russian for Nezavisimaya Gazeta ${ }^{4}$. The key-word search uncovered a total of 72 articles in Nezavisimaya Gazeta and 109 in The Globe and Mail. Of these, 33 articles in Nezavisimaya Gazeta and 31 articles from The Globe and Mail actually dealt with the issues of corporate social responsibility, resulting in a hit rate (the number of records the term/phrase appeared in relative to the total number of records in the search) of $35 \%$. To verify if any articles might have been missed through the key word search, the micro-films of the 2004 issues of The Globe

3 The linguistic tradition of discourse analysis (Fairclough, 1995; Fowler, 1991; van Dijk, 1988) considers media text as an object of analysis itself, while the sociological tradition treats media texts as windows into the human experience and as qualitative data: "by qualitative data we mean text: newspapers, movies, sitcoms, email traffic, folktales, narratives, and life stories" (Ryan/Bernard, 2000: 769). The linguistic and the sociological traditions similarly pay attention to the social, historical, economic, cultural, and political context in which the media text is embedded, and untangle the purpose with which the media text was written. Yet, unlike sociologists, linguists analyze the role of tenses, grammatical structures, sequence and connections between phrases, word choice, in serving these purposes. While the linguistic analysis of media text would be quite insightful, it would require a separate study beyond the current project that my essay reports.

4 Scholars who study corporate social responsibility in Russia were consulted to ensure the adequacy of the key words in translation. 
and Mail and the hard copies of the 2004 issues of Nezavisimaya Gazeta were screened as well, but the verification did not reveal any new articles.

In line with the inductive approach to thematic analysis (Denzin/Lincoln 2000:637; also Ryan/Bernard 2000; Patton 2002:453), the coding schema was built in course of my interaction with the data. Carefully reading the articles, and looking for categories in which corporate social responsibility was portrayed, first I discovered that in both newspapers corporate social responsibility was discussed from the perspectives of three dominant groups - corporate (business), state, and civil society. Then I noted what areas of activity (for example, environmental protection, patronage of science and culture, development of social infrastructure) and rationales for pursuing them (for example, guilt, compassion, fear) were discussed in application to the three different perspectives in Russia and in Canada. Whenever I found a new category, I reexamined the previously analyzed articles to verify whether this category may be present there.

\section{Results}

Both in Nezavisimaya Gazeta and in The Globe and Mail the articles discussed corporate social responsibility from the perspectives of the three key stakeholders: business, civil society, and the state.

\section{Portrayals of corporate social responsibility from the business perspective}

Table 1 summarizes the portrayals of corporate social responsibility from the perspective of the business in the two newspapers (see Table 1).

The discussion of corporate social responsibility from the business perspective in Nezavisimaya Gazeta concerned the functioning of the Russian companies at home. Russian companies working abroad and foreign companies working in Russia were not mentioned in the discussion. The notion of corporate social responsibility from the corporate perspective is summarized by the following quote:

The voluntary acceptance of social responsibility by the Russian business community and particular companies is not a social licence fee for commercial activity, nor just goodwill. Social responsibility of business is the precondition for the long-term success of the companies themselves and of the society's wellbeing. (Social charter of business, November 16, 2004).

The depicted areas of activity in the field of corporate social responsibility when discussed from the business perspective were the social policy areas where particular deficiency and need was identified. These were subsidized housing, health care and pension benefits for the employees, support of the development of communication and transport infrastructure in the regions, support of extended care and rehabilitation programs for persons with disabilities, 
investment into construction of schools and hospitals in the communities, investment into the community library and information resources, environmental protection, and patronage of science and culture:

The Foundation of Support of the Russian Science... established in 2000 by three quite well-known oligarchs - Deripaska, Mamut and Abramovich is yet the only foundation in Russia which ...donated the money to support the best young scholars in the [Russian] Academy [of Sciences]. (Oligarchs have once again supported the Russian Academy of Sciences, April 9, 2004).

Table 1 Portrayals of corporate social responsibility from the business perspective

\begin{tabular}{|c|c|c|c|}
\hline \multicolumn{2}{|c|}{ Nezavisimaya Gazeta } & \multicolumn{2}{|c|}{ The Globe and Mail } \\
\hline Areas of activity & Depicted reasons & Areas of activity & Depicted reasons \\
\hline $\begin{array}{l}\text { Health care; pensions; } \\
\text { development of transport } \\
\text { infrastructure; support of } \\
\text { educational system; } \\
\text { support of science and } \\
\text { culture; support of local } \\
\text { communities; employee } \\
\text { participation; health and } \\
\text { safety at workplace; } \\
\text { environmental protection }\end{array}$ & $\begin{array}{l}\text { - Voluntary adherence to } \\
\text { self-regulation } \\
\text { - Recognition of the } \\
\text { social needs } \\
\text { - Compassion with the } \\
\text { vulnerable populations } \\
\text { - Commitment to social } \\
\text { justice } \\
\text { - Aspiration to increase } \\
\text { the equality of } \\
\text { opportunities for all } \\
\text { citizens } \\
\text { - Aspiration to "help out } \\
\text { the state" }\end{array}$ & $\begin{array}{l}\text { Inducing suppliers to } \\
\text { abide to standardized } \\
\text { voluntary code of } \\
\text { conduct for socially } \\
\text { responsible business } \\
\text { practice; labour policy; } \\
\text { employee } \\
\text { participation; health } \\
\text { and safety at } \\
\text { workplace; global } \\
\text { development; } \\
\text { protection of the } \\
\text { environment }\end{array}$ & $\begin{array}{l}\text { - Sharing } \\
\text { international } \\
\text { standards of } \\
\text { business ethics } \\
\text { such as } \\
\text { transparency and } \\
\text { enhancement of } \\
\text { sustainable } \\
\text { economic growth } \\
\text { - Adherence to the } \\
\text { principles of } \\
\text { sustainable } \\
\text { development of } \\
\text { global } \\
\text { communities } \\
\text { - Commitment to } \\
\text { social justice and } \\
\text { ethical labour } \\
\text { practices in the } \\
\text { international } \\
\text { marketplace }\end{array}$ \\
\hline
\end{tabular}

The depicted goals of businesses were voluntary adherence to self-regulation, recognition of the social need, compassion with the vulnerable social groups, commitment to social justice, and creation of the society of equal opportunities.

The foundation "Open Russia" was created by UKOS to finance the functioning of 78 rehabilitation centres for children with disabilities. (It is easier to trash a 
good cause then to resurrect it. UKOS is a business of a new, unusual for Russia, type. March 19, 2004).

The article where this quote appeared was published shortly after the start of the UKOS case and aimed at presenting a comprehensive and positive portrayal of the company. The case of UKOS is a very significant event in terms of businessgovernment relations that happened in 2004. As I pointed out earlier, in Russia the state has traditionally penetrated the entire economic system, not only by creating and administering the rules of the game, but by managing the economic activities of the players on both the macro and the micro levels. The state authority and supremacy over the economy and its agents, although somewhat decreased during the presidency of Boris Eltzin, never disappeared from the Russian institutional and cultural framework (Krasin 2004), and was considerably reinforced during the presidency of Vladimir Putin. It is also important that the names of the oligarchs have been associated to many Russians not only with the controversial experiences of privatization, but also with the profound economic crisis and social degradation that accompanied it (Lane 1999; Rimashevskaya 2005). Moreover, the Russian oil industry, by being a major source of tax revenue and wealth, is not only a major site of struggles and controversies between the power holders within Russia, but also has an international dimension, being a point of strategic interest for international corporations, international financial institutions, and Western governments (Lane 1999). The newspaper representation of the UKOS case, as well as the general focus of the discussions of corporate social responsibility on the companies within the extraction industry, reflects these complex controversies between the state and the corporate sector, the notorious history of privatization and the power struggles, and simultaneously appeals to the members of the public, highlighting the company's social commitments in an effort to showcase the other side of the issue and to create the company's favourable social profile. Thus it is not surprising that in Russia the discussion of corporate social responsibility from the business perspective focused predominantly on the extraction and primary processing sectors (such as oil and gas companies, petroleum engineering companies, producers of steel, aluminium, and so on), while the Canadian articles spoke about a diversity of various businesses, including those in telecommunications, retail, pharmaceutics, and automobile production. In Russia corporations were presented willing to participate in the development and implementation of an inclusive social policy in partnership with the other social actors, such as the state and civic organizations:

The situation [of crisis in the social sphere in Russia] must be changed. It is necessary to develop a long-term strategy of social modernisation and a plan for [its] realisation. Obviously, this task may be achieved by uniting the efforts of ...the federal and regional government, enterprises, and the civil society, various cultural, educational, religious groups... We must help each other. (Overcoming 
inequality is a way to long-term stability. A system enabling active population to realize their rights needs to be developed in Russia. February 19, 2004).

The article asserted the willingness of big business to invest financial and professional resources to improve the quality of life of the country's population. Corporations were portrayed as acknowledging social inequality in Russia as inequality of opportunities, willing to collaborate with the state to develop and implement the social policy that will create equal opportunities for all people, and willing to contribute their financial, managerial, and intellectual resources towards this purpose.

As I already pointed out, the discussion of corporate social responsibility from the business perspective in The Globe and Mail unfolded in application to the functioning of both Canadian and foreign companies in Canada and abroad. The areas of activity, summarised in Table 1, were however the same regardless of the type of the company and its location. In contrast to Nezavisimaya Gazeta, which portrayed socially responsible corporations as providing the essential social services to employees and communities and thus filling the social policy gaps, The Globe and Mail focused on the social impacts of corporate activities in terms of environmental security and sustainable social development. The reasons for socially responsible behaviour presented in The Globe and Mail were voluntary adherence to the international standards of business ethics such as transparency of business operation, community development, environmental protection, social justice, and ethical labour practices in the international marketplace:

Nexen Inc. of Calgary has been pumping oil out of Yemen for a decade without a single interruption - and president Charles Fischer says that's no coincidence. For Mr. Fischer the unimpeded flow of 230, 000 barrels a day is testimony to the Yemeni people's regard for his company and Nexen's determination to leave a legacy deeper than a hole in the sand. (Gordon Pitts. June 3, 2004).

The depictions of corporate social responsibility from the business perspective in Nezavisimaya Gazeta made reference to the rules and norms developed and institutionalised at the inter-firm level (for example, the Social Charter of the Russian Business), but no mention was made about institutionalisation of corporate social responsibility within the company. In contrast, The Globe and Mail depicted corporate social responsibility as an integral part of the executives' jobs:

Charles J. Gagnon has been appointed Vice-President, Corporate Culture and Social Responsibility. Mr. Gagnon's appointment will include auditing, monitoring, implementing and applying policies and practices in line with the Company's guidelines concerning employee participation, social responsibility and ethics. (Tembec. October 21, 2004). 


\section{Portrayals of corporate social responsibility from the perspective of the civil society}

The second key stakeholder from whose perspective corporate social responsibility was discussed was the civil society. In The Globe and Mail, as shown in Table 2, there was a noticeable change in the presentation of the reasons, while the areas were similar to those presented from the business perspective (see Table 2).

Table 2 Portrayals of corporate social responsibility from the civil society perspective

\begin{tabular}{|c|c|c|c|}
\hline \multicolumn{2}{|c|}{ Nezavisimaya Gazeta } & \multicolumn{2}{|c|}{ The Globe and Mail } \\
\hline Areas of activity & Depicted reasons & Areas of activity & Depicted reasons \\
\hline $\begin{array}{l}\text { Health care; } \\
\text { pensions; } \\
\text { development of } \\
\text { transport } \\
\text { infrastructure; } \\
\text { support of } \\
\text { educational system; } \\
\text { support of science } \\
\text { and culture; support } \\
\text { of local communities; } \\
\text { employee } \\
\text { participation; health } \\
\text { and safety at } \\
\text { workplace; } \\
\text { environmental } \\
\text { protection }\end{array}$ & $\begin{array}{l}\text { - Acceptance of the } \\
\text { temporary necessity at } \\
\text { the time of } \\
\text { transition/crisis to 'fill } \\
\text { in' for the state social } \\
\text { policy } \\
\text { - Pressure from the } \\
\text { international business } \\
\text { community as a } \\
\text { prerequisite for } \\
\text { 'joining the club' }\end{array}$ & $\begin{array}{l}\text { Inducing suppliers to } \\
\text { abide by standardized } \\
\text { voluntary code of } \\
\text { conduct for socially } \\
\text { responsible business } \\
\text { practice; labour and } \\
\text { employment policy; } \\
\text { employee } \\
\text { participation; health } \\
\text { and safety at } \\
\text { workplace; global } \\
\text { development; } \\
\text { protection of the } \\
\text { environment }\end{array}$ & $\begin{array}{l}\text { - External pressure on } \\
\text { corporations from the } \\
\text { international, national } \\
\text { and local NGOs, } \\
\text { consumer groups, and } \\
\text { other civil society actors } \\
\text { that urge them to: } \\
\diamond \quad \text { Accept ethical } \\
\text { standards of business } \\
\text { practice } \\
\diamond \quad \text { Adhere to ethical } \\
\text { principles in labour } \\
\text { relations } \\
\diamond \quad \text { Respect the local } \\
\text { communities and the } \\
\text { environment } \\
\text { - Internal pressure from } \\
\text { within the business } \\
\text { community to maintain } \\
\text { the fairness of } \\
\text { competition } \\
\text { - Pressure from } \\
\text { individual citizens acting } \\
\text { in a consistent manner }\end{array}$ \\
\hline
\end{tabular}

As demonstrated in Table 2, emphasis was placed on the external pressure on the corporations from the international, national and local non-governmental organizations, consumer groups, and other civil society actors that urge them to 
accept better standards of business practice, respect ethical standards in labour relations, and be respectful of the local communities and the environment. Internal pressure within the business community to maintain the fairness of the competition was also acknowledged as a reason for corporate social responsibility. The companies that have already agreed to adhere to ethical labour standards and eliminated sweatshop practices, wanted all businesses to do the same, to prevent that any market player may "benefit" from low production costs based on unethical and / or ecologically detrimental production practices. The activities of civil society actors were not portrayed as direct causes of changes in corporate behaviour, but as catalysts of public debate about corporate social responsibility that makes corporations pay attention to their public image:

Long the target of the anti-globalization movement, Gap Inc. yesterday released a sweeping report on its monitoring and enforcement of labour standards among its global suppliers, a move that activists hope will force other US and Canadian retailers to step up their own efforts. (Gap pressures other retailers with first report on sweat shops. May 13, 2004).

Actions and decisions of individuals, often in a consistent and organized pattern, have been also highlighted as a channel by which the civil society influences the business practices, for example in the sphere of labour relations:

A survey of more than 800 MBAs from 11 leading North American and European schools found a substantial number would accept a lower pay check in order to work for an organization with a reputation for corporate social responsibility and ethics. (MBAs will take lower pay if employer is ethical. August 13, 2004).

In Nezavisimaya Gazeta the presentation of reasons for adhering to the principles of corporate social responsibility from the perspective of the civil society included the discussion of pressure on big business from international organisations like the World Bank, but not from the individual citizens or consumer groups:

The key question for the World Bank is a company's reputation, and by far not all the Russian companies have a reputation that would be attractive for the World Bank. (James Wolfenson may share information. February 4, 2004).

As portrayed from the civil society perspective, the Russian companies started to accept the principles of corporate social responsibility because of desire to join the international business community, where adherence to certain social and ethical standards is a necessity. However, the voice of the civil society institutions in the discussion of corporate social responsibility in Nezavisimaya Gazeta was very weak. It was left out due to the strong traditions of the media control by the state, compounded in the 1990s by the oligarchic control, and by the renewal of administrative pressures from bureaucratic structures during Putin's presidency (Chumikov 2002). Marginal presence of the voice of the civil 
society in the discussion of corporate social responsibility in Russia is also consistent with Krasin's (2004) argument that the civil society in Russia is yet quite underdeveloped and weak, and the civic groups have limited resources and capability to voice their concerns and their interests.

\section{Portrayals of corporate social responsibility from the state perspective}

In Russia the emphasis in the discussion of corporate social responsibility from the perspective of the state - the last, but not the least stakeholder - was on corporations as providers of essential social services to their employees and local communities under conditions of a deficient health care, pension, and social security system:

The Russian business leaders consider expenditures in [social sphere] areas as an anomaly. They expect that the state will eventually develop a comprehensive social policy and the need for them to share the responsibility for the maintenance of the social safety net will disappear. (Corporation as a social institution. March 23, 2004).

As this quote illustrates, from the perspective of the state corporations may not be willing to become permanent providers of social services, expecting this to be the role of the state. However, large business may be amenable to do it as a short-term solution. It is very important to mention in this connection that although the Russian government has always called its reforms "social", it has increasingly placed responsibility for financing the social support system on individuals and firms (Rimashevskaya 2005). Thus in Russia corporations were reproached for reluctance in accepting corporate social responsibility as their permanent obligation and duty. The reasons for corporate social responsibility from the perspective of the state were using one-time charitable actions as a means for avoiding taxes or receiving taxation benefits. Hence the quite unusual (in terms of a Western conceptualisation) definition of corporate social responsibility by Alexey Kudrin, Minister of Finance of the Russian Federation:

There are three aspects to what I personally consider corporate social responsibility. First of all this is the payment of taxes. Honestly, not via the offshore companies. Second, it is charity and patronage. I stress that taxes are of primary significance, because if taxes have not been paid in full because of offshore machinations, and then the company declares making an investment into charity, this is a false charity And third, it is the support of those political forces that care for the development of the country, including its democratization. (OPEK cannot lay down the law for Russia. April 27, 2004).

What Kudrin talks about is that paying taxes, which ensures the flow of resources into the budget, is a significant sustainable expenditure for a corporation, but can hardly boost its reputation because there is nothing spectacular in complying with the laws. Thus from the state perspective, 
corporate social responsibility becomes institutionalized as a means of reducing taxes through one-time donations to charities. This both builds a good public profile, and saves money. Hence the key theme emerging from the discussion of corporate social responsibility from the state perspective in Nezavisimaya Gazeta was the aspiration of the state to develop and implement a regulatory system in the area of corporate social responsibility. This aspiration, as presented in the articles, had two interconnected goals. The first was to use a part of corporate profits to finance priority policy areas. The second was to develop the mechanisms of state control over business, making it subordinate to the rule of the state. Using the non-compliance with the principles of corporate social responsibility as grounds for prosecution, the state could acquire a powerful means of control over the business activities. The aspiration to introduce formal accountability over corporate social activities was legitimized by arguing that redistribution of profits and wealth is needed to ensure greater economic equality in Russia:

What's the President's understanding of corporate social responsibility? Some businessmen believe that Putin considers that privatization led to social injustice, which should now be levelled out. Thus big business must 'pay its dues'. (Oligarchs knock at the President's door. June 3, 2004).

It seems that the state wants to dictate to businessmen what policy issues they must resolve and how much they must spend. (Volsky did not succeed in supporting the President. January 19, 2004).

[Prime Minister Mikhail Fradkov] declared that there are reserves to increase the taxation of the extraction companies. It looks like a full-scale program of expropriation of revenues from the business sector - on one hand, increased taxation, on the other - "voluntary" participation in social projects under the guise of corporate social responsibility. And if somebody disagrees, they may have to move to the neighbourhood of Mikhail Khodorkovsky. (Fradkov has found who is guilty of Russia's low competitiveness. July 9, 2004).

As these three quotes demonstrate, the articles are quite critical of the attitudes of the state with regards to corporate social responsibility. They point out that corporate social responsibility may not be reduced to coercive charity and that the increased pressure from the state may increase corruption and reduce economic activity. The paradox of the situation is that unlike in the West, the government is using the concept of corporate social responsibility as a measure of administrative control over the business, and because of this, corporations feel obligated to report to the state, not to the public or to the business community, about the extent of their social responsibility, not to the public:

The "sharks" of capitalism hurry to affirm [to the state] their willingness to be very socially responsible. (It is not necessary to row - but why get on the knees? July 1, 2004). 
As demonstrated in Table 3, unlike in Russia, in Canada the state was not portrayed as the most significant stakeholder in determining the scope of corporate social responsibility, being only marginally present in references to broad regulatory and institutional frameworks that influence the functioning of the markets.

However, the limited reach of the state's regulatory capacity over the business activities, particularly regarding the multi-national corporations, was a subject of concerns regarding the big business' willingness to responsively use its tremendous power and resources:

Table 3 Portrayals of corporate social responsibility from the state perspective

\begin{tabular}{|c|c|c|c|}
\hline \multicolumn{2}{|c|}{ Nezavisimaya Gazeta } & \multicolumn{2}{|c|}{ The Globe and Mail } \\
\hline Areas of activity & Perceived reasons & Areas of activity & Perceived reasons \\
\hline $\begin{array}{l}\text { Health care; pensions; } \\
\text { development of transport } \\
\text { infrastructure; support of } \\
\text { educational system; } \\
\text { support of science and } \\
\text { culture; support of local } \\
\text { communities; employee } \\
\text { participation; health and } \\
\text { safety at workplace; } \\
\text { environmental protection }\end{array}$ & $\begin{array}{l}\text { - Desire to 'buy a } \\
\text { pardon' for the } \\
\text { gratuitous privatisation } \\
\text { and to reduce taxes by } \\
\text { donating money to } \\
\text { charities } \\
\text { - Pressure from the } \\
\text { international business } \\
\text { community as a } \\
\text { prerequisite for 'joining } \\
\text { the club' }\end{array}$ & $\begin{array}{l}\text { Inducing suppliers to } \\
\text { abide by standardized } \\
\text { voluntary code of } \\
\text { conduct for socially } \\
\text { responsible business } \\
\text { practice; labour and } \\
\text { employment policy; } \\
\text { employee participation; } \\
\text { health and safety at } \\
\text { workplace; global } \\
\text { development; protection } \\
\text { of the environment }\end{array}$ & $\begin{array}{l}\text { - Preference for } \\
\text { diffused } \\
\text { influence from } \\
\text { the NGO sector } \\
\text { over concrete } \\
\text { regulation of } \\
\text { business activity } \\
\text { by the state }\end{array}$ \\
\hline
\end{tabular}

When corporate power and production have become truly global, the role of the corporation seems to be shifting. Unprecedented business success has brought validation, but it has also fuelled greater expectations and a more intense focus on the social costs of capitalism. Those include the impact on the global environment, working conditions in developing nations and the limited reach of regulations in any one country. (Corporate social responsibility: 2nd annual ranking. February 25, 2004).

As this quote exemplifies, the Canadian articles portrayed concerns about the consequences of the globalizing capitalism, while acknowledging that the solutions may not be readily available. Unlike in Russia, corporate social responsibility was portrayed as an area of business activity which is moderated by the society's institutional structure, social norms and values, but not directly regulated by the governmental or inter-governmental bodies. Thus in Canada no mention was made that the state should or may coerce corporations to be more 
socially responsible by using the mechanisms of direct influence and control, although the state (in partnership with other states in the international community) was portrayed as capable of supporting the development of the international norms and values and of a climate that would encourage social responsibility of business. This model of state-business relations is embedded in the liberal traditions of the Canadian economic history.

\section{Discussion}

\section{Key findings and their conceptual and empirical relevance}

Despite the abundant literature on corporate social responsibility, relatively little attention has been paid to the representation of corporate social responsibility in the news, particularly in respect to the post-communist countries, and to how media representation of corporate social responsibility is embedded in the society's institutional structure. This was a significant conceptual and empirical research gap that my study started to address. The comparative character of this study was advantageous for discerning similarities and differences of portrayals of corporate social responsibility in the Russian and the Canadian newspaper, and highlighting the importance of institutional structures and models of statebusiness relationship in analyzing corporate social responsibility in different countries.

This study found that articles published in Nezavisimaya Gazeta and in The Globe and Mail featured different meanings of corporate social responsibility that varied depending on the perspective from which it was discussed. The conceptual and empirical contribution of this study points out that perspective from which corporate social responsibility is portrayed is important. The meaning of corporate social responsibility may differ from the perspectives of business, state and civil society, and placing the themes discerned from the perspective of different stakeholders in the society's institutional context, as suggested by cross-cultural research on business ethics and corporate culture (Puffer/McCarthy 1995).

In effect, the themes uncovered in the portrayals of corporate social responsibility in the Russian newspaper were consistent with the analyses of the current Russian political and legal culture that "attempts to legislatively construct a democratic market economy", outlined in the research literature (Skyner 2003). They were also consistent with the analyses of the state-business relations in Russia offered by Radaev (2000), who claims that in its economic activities the state seeks to establish control through utilization of asymmetric power relations and the extraction of administrative and political rent.

Thus from the business perspective corporate social responsibility in Russia was portrayed as businesses' voluntary commitment to social development, yet from 
the state perspective it was portrayed as coerced accountability of the business to the state on the basis of a formalized system of rules, standards, and norms. Since the extraction industries are the major source of revenue and the site of the ongoing struggle for economic and political power in Russia (Lane 1999), corporate social responsibility was discussed particularly in application to these companies, while in Canada it was discussed in more diverse contexts, both domestic and international. While concerns about the implications of corporate social responsibility for the society were present in both cases, in Russia, unlike in Canada, the background for the discussion was the more general problem of inadequate public funding of the social policy (including such essential areas as healthcare and pensions). While concern about the social policy was also present in connection to corporate social responsibility in Canada, it stemmed from the discussions about whether the global capitalism may make sustainable commitments to the goals of social development.

Considerable debate has been ongoing in the academic literature about the limits to corporate social responsibility and the extent to which capitalism can be caring (Galaskiewitz 1991; Shamir 2004a, 2004b; Acutt/Medina-Ross 2004). "The argument advanced is that, by virtue of their very nature, trans-national companies cannot become fully responsible and accountable citizens. Nonetheless, they can be induced to transform themselves in ways that may be compatible with socially and environmentally desirable objectives" (Palacios 2004). Palacios (2004) highlights the potential of NGOs and social movements (for example, the anti-globalization social movement) to become civil regulators and push for the introduction of binding rules and the construction of a governance framework capable of restraining and harnessing the power of corporations. Hence the theme that transpired in the portrayals of corporate social responsibility from the civil society perspective in The Globe and Mail, where international and domestic civil society organizations were presented as pressing the business for socially responsible behaviour. The presentation of the Russian state's attempts to coerce businesses into socially responsible behaviour, and the concerns in Canada about whether corporations are truly committed to the goals of social development and truly accountable to society, resonated with the discussion of pros and cons of corporate accountability versus corporate responsibility in the research literature (Marsden 2000; Mendes 2003).

While The Globe and Mail expressed concern about the diminishing power of the state to mediate the practices of operation and the social consequences of global capitalism, this issue did not transpire from the discussion of the relations between the Russian state and the private sector. As depicted in the Russian articles, the state aggressively exercises pressure on corporations and uses the principles of corporate social responsibility developed in the West as a normative framework against which the enterprises are to be evaluated, and 
prosecuted in the case of deviance. This taps into the traditionally very strong state presence in all spheres of life in Russia reinforced during Putin's presidency (Krasin 2004).

Summarizing the above, the thematic diversity found in the depictions of corporate social responsibility in the two newspapers speaks to the diversity of institutional and cultural conditions in the two countries that shape the economic, social, and political sphere in Russia and in Canada in different ways. In both newspapers corporate social responsibility was portrayed from the perspectives of the three major stakeholders - business, civil society and the state. Portrayals of corporate social responsibility from the business perspective had considerable similarity in Russia and in Canada. With the somewhat stronger emphasis on the direct involvement into provision of social policy in the Russian case, there were no other remarkable differences in themes.

The main differences between Nezavisimaya Gazeta and The Globe and Mail concerned the depictions of corporate social responsibility from the civil society and the state perspectives. In Russia the civil society perspective on corporate social responsibility was quite limited, with the domestic and international civil society actors shown as having limited impact on corporations, in comparison to a much more direct and intense pressure on the business from the state. No thematic diversity was observed in Russia in terms of elaborating on the role of the civil society actors either domestically or internationally. This is largely accounted for by the institutional foundations of the Russian economic system, where the governmental control on the business is traditionally strong (Zhiltzov 1995), while the civil society organizations are still quite weak (Krasin/Rozanova 2004). By contrast in the Canadian articles, civil society was depicted as the principal stakeholder that necessitates corporate compliance with the international norms of ethical business practices, as not only organizations, but also individual citizens can make an impact on corporate behaviour through their economic and civic choices. This reflects the long standing traditions of communitarianism and civic participation, supported by the institutional structure of the Canadian society (Acland/Buxton 2000).

The fact that the portrayals of corporate social responsibility in Canada to a considerable extent focused on the low work safety standards in the companies operating outside of North America in the developing countries of Asia, Africa, and South America, made the discussion about the social implications of business in the Canadian newspaper considerably less dramatic than in Russia. This is an interesting finding in the light of the argument of Fowler (1991:12-13) and Hartley (1982:75-79) about the news values, such as cultural proximity and relevance, that are used by the media as filters for selecting newsworthy items and constructing the news. In the Russian case, corporate social responsibility was discussed in application to the activities of the notoriously famous oil companies and their interaction with the government, the topics that seem to 
reporters self-evidently meaningful. The meaningfulness and newsworthiness of these business-government interactions in Russia is reinforced by the configuration of the media control system (Fowler 1991:11), when the governmental officials have convenient access to the media and their opinions are easily screened by the journalists.

In this connection it is important to point out that, as I stated earlier, my analyses reveal the assertions and attitudes expressed in the articles published in the two newspapers towards corporate social responsibility from the perspective of the key stakeholders in the society. As the scholars of the media argued (Hartley 1982; Fowler 1991; Spigel 2001), these assertions and attitudes have been selected, filtered, and shaped according to the agendas of the socially, economically, and politically situated institutions of news production, and thus they need to be acknowledged not as reality per se, but as its media representation (Fowler 1991; Fairclough 1995).

\section{Implications for managers and practitioners}

From a managerial perspective my findings may indicate that the attention of the Russian state towards corporate social responsibility result not only from the authoritarian political culture (oriented to control of enterprises and coercion using administrative mechanisms), but also from the deficiencies in the social safety net. The fact that the state considers corporate social responsibility as one of the ways to address the problem of poverty in Russia, and that corporations (or some of them) agree to that, may speak above all to the degree of social need that necessitates the search for unconventional solutions (from a Westerner's point of view). Another implication of my findings that needs highlighting is that transparency of corporate governance and of the principles of business ethics to which the company adheres has been portrayed in both Canadian and Russian newspapers as an effective way to avoid tensions in businessgovernment relations around the issues of corporate social responsibility. A crucial implication of this for the managers is that ethical standards of business practices pay off in various cultural contexts, whereas non-compliance with these standards risks in losing social prestige and trust that ultimately result in economic losses, wherever the firm is located.

\section{Potential for further research}

Much further research is possible on the basis of this study. It would be exciting to compare the media discussion of corporate social responsibility with the business practices of companies in both countries. An empirical investigation of the latter could be done by means of a case study, or through interviewing the corporate leaders. It would be exciting to compare the portrayals of corporate social responsibility with the actual business practices in the two countries, and also to extend this comparison to other regions. While my study pointed out the 
themes and assertions in the representation of corporate social responsibility in the two newspapers, the next step would be to "drill" the surface of these texts by the methods of critical linguistics, and analyse how rhetorical devices are used in line with the various intentions of the communicators. Additionally, it would be relevant to investigate the construction of meaning by journalists who write about corporate social responsibility and by the audience who read their articles, using a combination of critical linguistic discourse analysis and ethnographic methods. Also, a larger study of the media portrayals of corporate social responsibility, including more sources both in print and in electronic media, could be conducted to test the insights revealed by my pilot project. In Canada it would also be interesting to compare the portrayals of corporate social responsibility in the anglophone and francophone media. The importance of corporate social responsibility and the diversity of its portrayals by the media, suggest that investigation of this area needs to continue.

\section{References}

Acland, C.R/Buxton, W.J. (2000): Harold Innis in the New Century: Reflections and Refractions. Montreal, McGill - Queen's University Press.

Acutt, N./Medina-Ross, V./O'Riordan, T. (2004): Perspectives on corporate social responsibility in the chemical sector: A comparative analysis of the Mexican and South African cases, in: Natural Resources Forum, 28, 4, 302-317.

Burgelman, J-C./Calabrese, A. (1999): Communication, Citizenship and Social Policy. Rethinking the Limits of the Welfare State. Lanham: Rowman \& Littlefield.

Caldwell, J. (2004): Convergence television: aggregating form and repurposing content in the culture of conglomeration, in Spigel, L. (ed.): Television after TV, Durham: Duke University Press, 41-74.

Chumikov, A. (2002): The Development of the Media as an Instrument of Democracy in Russia. Moscow: Moscow Lomonosov University Press.

Crouch, C./Streeck, W. (1998): Political Economy of Modern Capitalism. Thousand Oaks, CA: SAGE Publications.

Denzin, N./Lincoln, Y. (2000): Methods of collecting and analyzing empirical materials, in: Denzin, N./Lincoln, Y. (eds.): Handbook of Qualitative Research. California, Thousand Oaks: SAGE Publications, 632-645.

Fairclough, N. (1995): Media Discourse. London: Edward Arnold.

Folwer, R. (1991): Language in the News. Discourse and Ideology in the Press. London and New York: Routledge.

Galaskiewicz, J. (2001): Making Corporate Actors Accountable: Institution-Building in Minneapolis - St. Paul, in Powell, W.W./DiMaggio, P.J. (eds): The New Institutionalism in Organizational Analysis, Chicago and London: The University of Chicago Press, 293-310.

Habermas, J. (2000): The Public Sphere, in Readings in Contemporary Political Sociology, Oxford, UK: Blackwell Publishers, 288-289. 
Hall, P.A./Soskice, D. (eds.) (2001): Varieties of Capitalism: The Institutional Foundations of Comparative Advantage. Oxford, UK: Oxford University Press.

Hartley, J. (1982): Understanding News, London and New York: Methuen.

Horkheimer, M. (1975): Critical Theory. London: Continuum Publishers.

Krasin, Y. (2004): Public Policy and Public Sphere: Russian Problems/ Paper delivered at the XIX IPSA World Political Science Congress, Durban.

Krasin, Y./Rozanova, J. (2004): Public Sphere and Public Policy in Russia: Lessons of a Decade of UCGF Partnership, in: Sunker, H./Farnen, R./Szell, G. (eds.): Political Socialisation, Participation and Education: Change of Epoch, Processes of Democratization. Frankfurt am Main: Peter Lang Verlag, 187-201.

Lane, D. (1999): The Political Economy of Russian Oil. Lanham: Rowman \& Littlefield.

Leibfried, S. (2001): Welfare State Futures. Cambridge, UK: Cambridge University Press.

Mares, I. (2001): Firms and the Welfare State: When, Why, and How Does Social Policy Matter to Employers? in: Hall, P./Soskice, D. (eds.): Varieties of Capitalism: The Institutional Foundations of Comparative Advantage. Oxford, UK: Oxford University Press.

Marsden, C. (2000): The New Corporate Citizenship of Big Business: Part of the Solution to Sustainability? In Business and Society Review, 105, 1, 31-51.

McDaniel, S. (1997): Health Care Policy in an Aging Canada: The Alberta "Experiment", in Journal of Aging Studies, 11, 3, 13-27.

Mendes, E./Mehmet, O. (2003): Global Governance, Economy and Law: Waiting for Justice. New York, NY: Routledge.

Palacios, J.J. (2004): Corporate Citizenship and Social Responsibility in a Globalized World, in: Citizenship Studies, 8, 4, 383-403.

Patton, M.Q. (2002): Qualitative Research and Evaluation Methods. Thousand Oaks, CA: SAGE Publications.

Peregudov, S. (2000): "Big Russian corporation as a political actor"/ Paper delivered at the XVIII IPSA World Political Science Congress, Quebec City.

Powell, W.W./DiMaggio, P.J. (1991): The New Institutionalism in Organizational Analysis. Chicago and London: The University of Chicago Press.

Puffer, S.M./McCarthy, D.J. (1995): Finding the common ground in Russian and American Business Ethics, in: California Management Review, 37, 2, 29-46.

Radaev, V. (2000): The Market as an Object of Sociological Investigation, in: Russian Social Science Review, 41, 5, 23-39.

Rimashevskaya, N. (2005): The Social Vector of the Development of Russia, in: Sociological Research, 44, 5, 5-52.

Rozanova, J. (2005): Welfare State is Dead - Long Live Welfare Corporation? in: Szell, G./Bosling, C-H./Hartkemeyer, J. (eds.): Labour, Globalization and The New Economy. Frankfurt am Main: Peter Lang Verlag, 209-217

Rozanova, J. (2006, in press): Behind the Screen: the Role of State-TV Relationships in Russia, 1990-2000, in: Canadian Review of Sociology and Anthropology. 
Ryan, G.W/Bernard, H.R. (2000): Data Management and Analysis Methods, in: Denzin, N./Lincoln, Y. (eds.): Handbook of Qualitative Research. CA, Thousand Oaks: SAGE Publications, 769-802.

Salais, R. (1998): Institutions et Conventions - Le réflexivité de l'action économique. Paris: Editions de l'EHESS.

Scharpf, F.W./Schmidt, V.A. (eds.) (2000): Welfare and Work in the Open Economy: From Vulnerability to Competitiveness. Oxford, UK: Oxford University Press.

Shamir, R. (2004): Between Self-Regulation and the Alien Tort Claims Act: On the Contested Concept of Corporate Social Responsibility, in: Law \& Society Review, 38, 4, 635665.

Shamir, R. (2004): The De-Radicalization of Corporate Social Responsibility, in: Critical Sociology, 30, 3, 669-690.

Silverman, D. (2000): Analyzing Talk and Text, in: Denzin, N./Lincoln, Y. (eds.): Handbook of Qualitative Research. California, Thousand Oakes: SAGE Publications, 821-834.

Skyner, L. (2003): Public Power and Private Interests: the Media, the Law and Democracy in Russia, in: Perspectives on European Politics and Society, 4, 2, 265-298.

Spigel, L. (2001): Welcome to the Dreamhouse: Popular Media and Postwar Suburbs. Durham, NC: Duke University Press.

Strange, S. (2000): States and Markets. London, UK: Pinter Publishers Ltd.

Teun A. van Dijk (1988): News Analysis. Case Studies of International and National News in the Press. Hillsdale, New Jersey: Laurence Erlbaum Associates.

Wetherell, M./Taylor, S./Yates, S. (2001): Discourse as Data: A Guide for Analysis. London: SAGE Publications.

Zhiltsov, E. (1995): Economic Analysis of the Public Sector in Russia. Moscow: Nauka. 